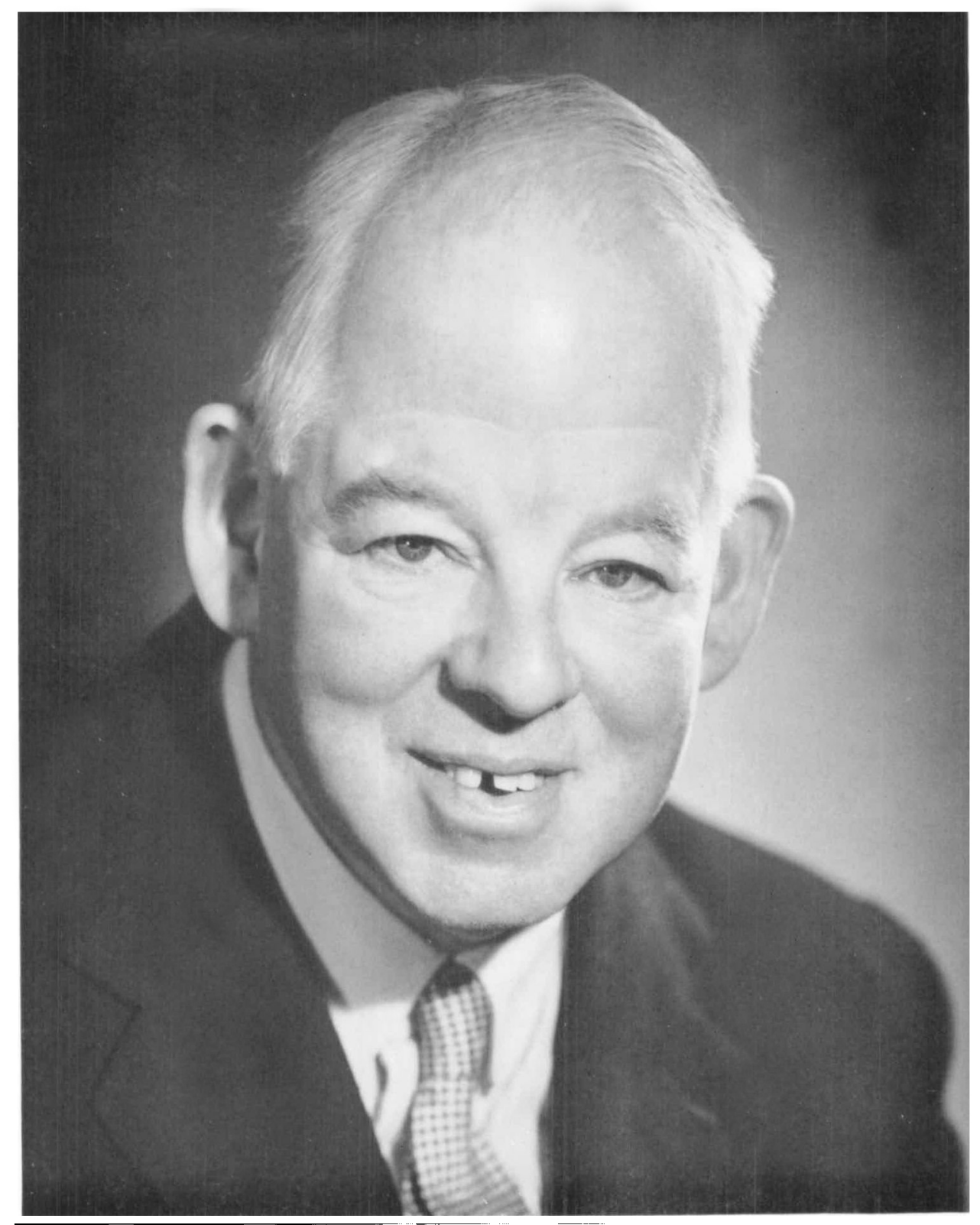

(Photograph by Walter Bird)

SIR IAN RICHMOND

PRESIDENT I $964-5$ 


\section{SIR IAN RICHMOND}

For the first time in this century, the Society of Antiquaries has lost a serving President by mortality. Ian Richmond's tenure of the office was most lamentably brief, and there is much else in his premature death that his friends and the wide world of classical studies must long deplore. At sixty-two his mind was in its prime, and his work-especially his writing-was unfinished.

His life was undramatic and the story is soon told. He was born in I9O2 at Rochdale, within the Lancashire border, the twin son of an esteemed local doctor; and he went to Ruthin School in north Wales-a school with a strong cultural bias fostered by our Fellow, E. W. Lovegrove, an enthusiastic and eloquent exponent of medieval architecture. Whether from Lovegrove or from his reading of Haverfield on Roman Britain or from both, the young Richmond emerged with a somewhat unwieldy predilection for archaeology, so that when he went up to Corpus Christi College at Oxford he probably spent a disproportionate share of his time upon what was then an esoteric sideline. The resultant Second in Greats ( 1924 ) inadequately reflected a first-class brain, but did not stand in the way of his subsequent election to the Craven Fellowship and Goldsmiths Senior Studentship of Oxford and to the Gilchrist Scholarship of the British School at Rome.

For two years he was a student of the School, and, after four years at Belfast as Lecturer in Classical Archaeology and Ancient History, he returned in I 930 to Rome as Director of the School. He there succeeded Thomas Ashby, who had died tragically in that year. Ashby's tastes had lain in the direction of topographical survey and other aspects of field-work; and as an act of piety his successor prepared Ashby's unfinished book on the Roman aqueducts for the press (Oxford, I 935). Meanwhile, in the year of his appointment, Richmond's own book on The City Wall of Imperial Rome, inspired by Ashby but already displaying the acumen and freshness of his young mind and the precocious ripeness of his scholarly understanding, had also been published. Before the age of thirty his reputation was established.

On leaving Rome he was confronted for a moment with the possibility of succeeding J. P. Bushe-Fox as Chief Inspector of Ancient Monuments under the (then) Office of Works. Instead, however, he returned to academic life, and in I 935 became Lecturer in Roman-British Studies at King's College, Newcastle-upon-Tyne. His Lecturership first became a Readership and then, in 1950, a Professorship, which he held until he was invited in $195^{6}$ to fill the new Chair of the Archaeology of the Roman Empire at Oxford, with a Fellowship of All Souls.

His work lay primarily, though not exclusively, in the field. His first venture was as an undergraduate when, in I 922 , on the prompting of R. G. Collingwood and Miss M. V. Taylor, he took part in the excavation of Segontium, the Roman fort at Caernarvon, and so incidentally came into contact with the writer of the present note. I well remember the arrival of this shyly confident young man upon the scene, our first recruit (Tessa's and mine) from the outside world. It so 
happened that Alfred Clapham was staying with us at the time, and fate thus brought together three unsuspecting future Presidents of the Society upon what was in every sense a pioneer-excavation. At the moment of Richmond's advent the position of the cellar strong-room of the fort's headquarters had just been identified; and now a trowel was promptly placed in our recruit's unpractised hands, and for a week or more upon his hands and knees and with meticulous care he slowly scraped away stratum after stratum in that richly rewarding structure whilst I sat upon the edge with my drawing-board and notebook. In after years we recalled the episode with a certain measure of amused satisfaction as a major landmark in our archaeological careers and our mutual friendship, and possibly as a little landmark in the development of archaeological technique.

Thereafter he quickly began to undertake excavations on his own, always with a preference for carefully selective small-scale operations rather than for the big battalions. Hadrian's Wall always attracted him, whether as an executive or as a critical and constructive observer. The Roman practice-camps at Cawthorn in Yorkshire provided him with a subject entirely after his own heart, and the report is a masterly example of his skill and tactical economy. Later he worked at Chester, South Shields, and elsewhere upon military sites, whilst in the Roman baths of Bath, the Silchester Roman church, and the Chedworth Roman villa he added materially to our understanding of familiar monuments of the civil zone. In latter years he directed two major projects: the excavation of Hod Hill in Dorset for the British Museum, and, with Dr. J. K. S. St. Joseph, of the great legionary fortress of Inchtuthil in Scotland. At Hod Hill he dug extensively into the Iron Age hillfort and made new sense of the little Roman fort which occupies one corner of it. I understand that substantially the whole of his report is in the press, and there is no doubt that in due course it will constitute one of his principal memorials. Of Inchtuthil, on which he was actually working during his last weeks, the published plan, however unfinished, will make this Agricolan fortress a type-site of its kind, and his distinguished partner will no doubt see to the rest.

This catalogue of sites, far from complete, will serve to illustrate the range of Richmond's interests. With the exception of Rome itself they were mainly focused upon Britain, though latterly he had begun to extend and had in fact designed to work in Spain shortly before his death. But his place lies in the direct line of descent from R. G. Collingwood and, behind him, Francis Haverfield, who made Roman Britain a specifically Oxford tradition, and it is entirely appropriate that Richmond should have returned there in his later years.

Whether or not of the overall stature of Haverfield, Richmond has left us work of which an unusual proportion will live, and the general indebtedness of RomanoBritish studies to his wise encouragement and ready advice is beyond calculation. His clear mind and quick apprehension, his capacity for forthright expression in speech or writing, his patient willingness to help, are within the knowledge of many and are cherished memories. Above all, his gift of friendship, warm and 
savoured by a puckish humour, will always remain in the thoughts of those many of us who knew him. We shall miss him very sadly as a scholar and as a companion.

It may be added that he became a Fellow of our Society in I 93 I, a Vice-President in 1 945-9 and 1957-9, Director in 1959-64, and President in 1964; a Fellow of the British Academy in 1947; received honorary doctorates from the universities of Edinburgh, Leeds, Belfast, Manchester, and Cambridge; was created C.B.E. in $195^{8}$, and was knighted in 1964 .

October 1965

R. E. M. W. 